\title{
The effect of sludge recirculation rate on a UASB-digester treating domestic sewage at $15{ }^{\circ} \mathrm{C}$
}

\author{
Lei Zhang, ${ }^{\mathrm{a}, \mathrm{b}}$, Tim L.G. Hendrickx ${ }^{\mathrm{a}}$, Christel Kampman ${ }^{\mathrm{a}}$, Grietje Zeeman ${ }^{\mathrm{a}}$, Hardy Temmink ${ }^{\mathrm{a}}$, Weiguang Li $^{\mathrm{b}}$, \\ Cees J.N. Buisman ${ }^{\mathrm{a}}$ \\ a) Sub-department of Environmental Technology, Wageningen University, P.O. Box 17, 6700 AA, \\ Wageningen, The Netherlands \\ (E-mail: tim.hendrickx@wur.nl, christel.kampman@wur.nl, grietje.zeeman@wur.nl, \\ hardy.temmink@wur.nl, cees.buisman@wur.nl) \\ b) School of Municipal and Environmental Engineering, Harbin institute of technology, 150090, Harbin, \\ China \\ (E-mail: lei_zhang25@yahoo.com, hitlwg@126.com)
}

\begin{abstract}
The anaerobic treatment of low strength domestic sewage at low temperature is an attractive and important topic at present. A UASB-digester system is one of the successful anaerobic systems to challenge low temperature and concentrations. The effect of sludge recirculation rate on UASBdigester treating domestic sewage at $15{ }^{\circ} \mathrm{C}$ was studied in this research. A sludge recirculation rate of $1 \%, 2.6 \%$ and $12.5 \%$ of the influent flow rate was investigated respectively. The results showed that the total COD removal efficiency rose with increasing sludge recirculation rate. A sludge recirculation rate of $1 \%$ of the influent flow rate leads to organic solids accumulation in the UASB. After the sludge recirculation rate increased from $1 \%$ to $2.6 \%$, the stability of the UASB sludge was substantially improved from 0.37 to $0.15 \mathrm{~g} \mathrm{CH}_{4}-\mathrm{COD} / \mathrm{g} \mathrm{COD}$, and the biogas production in the digester went up from 2.9 to $7.4 \mathrm{~L} / \mathrm{d}$. The stability of the UASB sludge and biogas production in the digester were not significantly further improved by increasing sludge recirculation rate to $12.5 \%$ of the influent flow rate, but the biogas production in the UASB increased from $0.37 \mathrm{~L} / \mathrm{d}$ to $1.2 \mathrm{~L} / \mathrm{d}$. It is recommended to apply a sludge recirculation rate of $2-3 \%$ of influent flow rate in a UASB-digester system.
\end{abstract}

Keywords

UASB, digester, low temperature, SMA, stability, sludge recirculation rate

\section{Introduction}

Given the potential advantages of anaerobic compared to aerobic sewage treatment (e.g. less energy consumption, energy production and a lower sludge production), its application at moderate and low temperatures $\left(\leq 20{ }^{\circ} \mathrm{C}\right)$ would be very attractive (Lettinga et al. 2001). High-rate anaerobic reactors, such as Expanded Granular Sludge Bed (EGSB) and Anaerobic Baffled Reactor (ABR), have been reported to successfully treat synthetic wastewater at low temperature $\left(10{ }^{\circ} \mathrm{C}-20{ }^{\circ} \mathrm{C}\right)$ containing mainly soluble chemical oxygen demand (COD) (McKeown et al. 2009, Langenhoff \& Stuckey 2000). However, at low temperatures $\left(6-15^{\circ} \mathrm{C}\right)$ the growth of methanogens is very slow and the hydrolysis of the biodegradable solids in sewage may be the rate limiting step of the process. (Leitão et al. 2006). As a consequence, suspended organic matter accumulates in the anaerobic reactor when the sludge retention time (SRT) is not sufficiently long (Luostarinen et al. 2007). The accumulated solids in the reactor replace the anaerobic biomass, and the biomass is also lost in the effluent by attachment to washed out solids. As a result, stability, specific methanogenic activity (SMA) and SRT of the sludge in a single Upflow Anaerobic Sludge Bed (UASB) reactor all decrease when the SRT becomes too short due to the organic solids accumulation. As a result, this sludge still requires stabilisation before appropriate reuse or final disposal (Seghezzo et al. 2006), and liquid effluent needs further treatment. The application of long SRT needs long HRT and therefore large reactor volume, which is economically not feasible. The combination of a UASB and a digester (U-D) has been shown to be successful to treat domestic sewage with high concentrations of suspended organic solids at low temperature (Mahmoud et al. 2008, Mahmoud et 
In this study, municipal sewage was treated in a UASB at $15{ }^{\circ} \mathrm{C}$. As shown in Fig. 1, sludge recirculation connects a UASB and digester. The un-stabilized suspended sewage COD that is captured by the UASB sludge bed is transferred to the digester, which is operated at $35^{\circ} \mathrm{C}$. At the same time, stabilized sludge from the digester is transferred to the UASB, herewith providing additional methanogenic biomass to convert soluble COD. In previous studies, the sludge recirculation rate was determined by control of the sludge bed height (Mahmoud et al. 2004, Álvarez et al. 2004). However, the data about sludge recirculation on the overall process is very limited, and the optimum for the treatment of domestic sewage at low temperature is still not clear. Yet, the amount of sludge that needs to be circulated is crucial to the viability of the U-D, since it determines the required energy input to heat the transferred sludge from $15{ }^{\circ} \mathrm{C}$ to $35{ }^{\circ} \mathrm{C}$. In this work, the effect of the sludge recirculation rate in U-D system on COD removal efficiency, bio-gas production, the stability and specific methanogenic activity (with acetate) of the U-D sludge, was investigated.

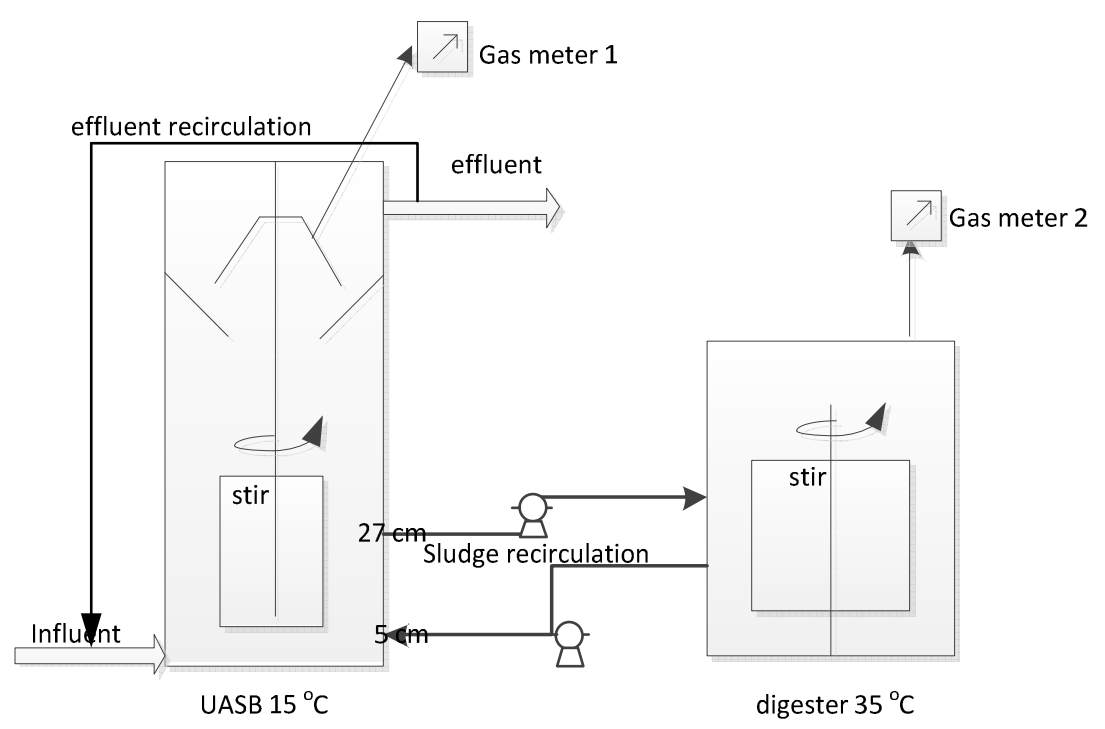

Figure 1. The pilot-scale UASB-digester system in this research.

\section{Method and materials}

\section{Inoculum and sewage}

The inoculum sludge used in the U-D system was taken from a primary sludge digester operated at $35^{\circ} \mathrm{C}$ at the wastewater treatment plant (wwtp) of Ede (NL). The screened $(<3 \mathrm{~mm})$ sewage came from a collecting system at the wwtp in Bennekom, the Netherlands. It was collected weekly and kept in a closed stirred tank at $5{ }^{\circ} \mathrm{C}$.

\section{UASB-digester (U-D) system}

A pilot scale U-D was operated to treat domestic sewage at $15{ }^{\circ} \mathrm{C}$ for a period of $372 \mathrm{~d}$. The influent flow rate was about $200 \mathrm{~L} / \mathrm{d}$. The following sludge recirculation rates were investigated: $1.8 \mathrm{~L} / \mathrm{d}$, $5.2 \mathrm{~L} / \mathrm{d}$ and $25 \mathrm{~L} / \mathrm{d}$ for $210 \mathrm{~d}, 70 \mathrm{~d}$ and $92 \mathrm{~d}$ respectively. Details of the U-D system are given in table 1. Effluent recirculation over the UASB was applied to increase the up-flow velocity from $0.26 \mathrm{~m} / \mathrm{h}$ to $0.5 \mathrm{~m} / \mathrm{h}$. The sludge bed height in the UASB was manually controlled to be less than 80 $\mathrm{cm}$. The excess sludge was discharged from the height of $67 \mathrm{~cm}$. Sampling points on the UASB reactor were located at 11.5, 27, 47 and $67 \mathrm{~cm}$ height. 
Table 1. The operational and design parameters of U-D in the research.

\begin{tabular}{lcc}
\hline & UASB & digester \\
\hline Total Height $(\mathrm{m})$ & 1.15 & 1 \\
Temperature $\left({ }^{\circ} \mathrm{C}\right)$ & 15 & 35 \\
Diameter $(\mathrm{cm})$ & 23.5 & 23.5 \\
Volume $(\mathrm{l})$ & 50 & 38 \\
HRT $(\mathrm{d})$ & 0.25 & $21 / 7.3 / 1.5$ \\
Effluent recirculation rate & $180 \%$ & - \\
Up-flow velocity $(\mathrm{m} / \mathrm{h})$ & 0.5 & - \\
Mixing condition $(\mathrm{rpm})$ & 0.2 & 84 \\
\hline
\end{tabular}

\section{Batch experiment}

Specific methanogenic activity (SMA) of the UASB sludge was determined in duplicate at $15{ }^{\circ} \mathrm{C}$. Serum bottles with a volume of $117 \mathrm{ml}$ were used in the test. The substrate was acetate with a starting concentration $1 \mathrm{~g} \mathrm{COD/L}$. The volume of UASB sludge was $60 \mathrm{ml}$. No trace nutrition was added, assuming this was sufficiently present in the sludge samples for the whole test period. The contents and headspace were flushed with nitrogen. The bottles with demi water and without any biomass were used as blanks. The volume of demi water was the same as the volume of the sludge samples. All the samples were incubated at $15 \pm 1{ }^{\circ} \mathrm{C}$ in a shaker with $120 \mathrm{rpm}$ in the dark. The pressure in the bottles was checked twice per day by hand digital pressure meter with a needle.

The stability test of both the UASB and the digester sludge was similar to the SMA test. The test temperature was $35{ }^{\circ} \mathrm{C}$, and it was performed without addition of substrate. During the test, the anaerobic degradable compounds were converted to methane. The test was ended when no further methane production was observed (i.e. no further increase in pressure). High value in the results of stability test shows that high anaerobic biodegradable organic compound is in the sludge, which means less stable. The volatile suspended solids (VSS) and total suspended solids (TSS) of the UASB and digester sludge sample in SMA and stability tests are shown in Table 2. The UASB sludge samples were taken at $11.5 \mathrm{~cm}$ height from the bottom of UASB reactor.

Table 2. the VSS and TSS concentrations of UASB and digester sludge samples in the SMA and stability test (samples are duplicate and the standard deviation is in the brackets).

\begin{tabular}{ccccc}
\hline $\begin{array}{c}\text { Date } \\
\text { (since the } \\
\text { operation }\end{array}$ & \multicolumn{2}{c}{ VSS concentration } & \multicolumn{2}{c}{ TSS concentration } \\
$\begin{array}{c}\text { UASB } \\
\text { started })\end{array}$ & sludge & $\begin{array}{c}\text { Digester } \\
\text { sludge }\end{array}$ & $\begin{array}{c}\text { UASB } \\
\text { sludge }\end{array}$ & $\begin{array}{c}\text { Digester } \\
\text { sludge }\end{array}$ \\
\hline 161 & $(\mathrm{~g} / \mathrm{L})$ & $(\mathrm{g} / \mathrm{L})$ & $(\mathrm{g} / \mathrm{L})$ & $(\mathrm{g} / \mathrm{L})$ \\
\hline 277 & $7.8(-)$ & $6.3(-)$ & $11(-)$ & $9.5(-)$ \\
307 & $13.1(0.13)$ & $7.4(0.1)$ & $18.6(0.15)$ & $11.7(0.04)$ \\
& $11.5(0.04)$ & $6.7(0.01)$ & $17.5(0.08)$ & $10.4(0.06)$ \\
\hline
\end{tabular}

For analysis of the gas composition a sample was taken with a $100 \mu 1$ syringe at the end of all the tests.

\footnotetext{
Analysis

Concentrations of nitrogen, methane, and carbon dioxide in the headspaces of the activity bottles were measured using a gas chromatograph (Interscience GC 8000 series) equipped with a thermal conductivity detector and two columns (Molsieve 5A $50 \mathrm{~m} \times 0.53 \mathrm{~mm}$ for $\mathrm{N}_{2}$ and $\mathrm{CH}_{4}$ and Porabond Q $50 \mathrm{~m} \times 0.53 \mathrm{~mm}$ for $\mathrm{CO}_{2}$ ). Injector and detector temperatures were respectively kept at 110 and $99{ }^{\circ} \mathrm{C}$, while oven temperature was $50{ }^{\circ} \mathrm{C}$. COD was performed using DrLange tubes (type 514).
} 


\section{Results and discussion}

\section{COD removal efficiency}

Table 3 shows the average removal efficiency of total, suspended, colloid and dissolved COD during the three different sludge recirculation rates. The total COD removal efficiency reached the best result with the highest sludge recirculation rate of $25 \mathrm{~L} / \mathrm{d}$. Compared to the other two lower sludge recirculation rates of $5.2 \mathrm{~L} / \mathrm{d}$ and $1.8 \mathrm{~L} / \mathrm{d}$, the higher dissolved COD removal efficiency was the main contributor to the improved total COD removal efficiency. Based on the amount of sludge transferred to the digester and the anaerobic biodegradability of the sewage, the improved $\mathrm{COD}_{\text {dissolved }}$ removal efficiency mainly increased due to the transfer and conversion of dissolved COD in the digester. However, the larger amount of anaerobic biomass provided to the UASB also contributed to the higher dissolved COD removal efficiency. The total COD removal efficiency was lower than expected at all sludge recirculation rates, a possible explanation for this will be discussed later.

Table 3. the summary of the suspended, colloid, dissolved and total COD removal efficiency, $\mathrm{n}$ is the numbers of samples (the efficiency was the average of all the samples).

\begin{tabular}{crlccc}
\hline $\begin{array}{c}\text { Sludge } \\
\text { recirculation } \\
\text { rate }(\mathrm{L} / \mathrm{d})\end{array}$ & $\mathrm{n}$ & $\mathrm{COD}_{\text {total }}$ & $\mathrm{COD}_{\text {suspended }}$ & COD $_{\text {colloid }}$ & COD $_{\text {dissolved }}$ \\
\hline 1.8 & 30 & $31.8 \pm 12.7$ & $61.9 \pm 17.7$ & $16.5 \pm 23.2$ & $6.3 \pm 8.6$ \\
5.2 & 7 & $32.2 \pm 8.1$ & $58.6 \pm 16.6$ & $19.1 \pm 16.5$ & $5.8 \pm 5.8$ \\
25 & 10 & $37.1 \pm 9.8$ & $58.1 \pm 21.2$ & $17.9 \pm 16.5$ & $17.1 \pm 11.5$ \\
\hline
\end{tabular}

\section{Stability and SMA of U-D sludge}

The results of the stability and SMA tests of the UASB and the digester sludge are shown in Table 4. The results of stability test with UASB sludge at a recirculation rate of $1.8 \mathrm{~L} / \mathrm{d}$ shows that this sludge is relatively unstable, i.e. it still contains considerable amounts of biodegradable solids and accumulation of such solids in the sludge bed. Thus, although the total COD removal efficiency was similar compared to the U-D system operation at a sludge recirculation rate of $5.2 \mathrm{~L} / \mathrm{d}$ as shown in Table 3, it was actually attributed to the organic solids accumulation. But the stability of UASB sludge was drastically improved after the sludge recirculation rate had increased from $1.8 \mathrm{~L} / \mathrm{d}$ to 5.2 L/d. The stability of the UASB sludge only improved 33 percent by further increasing the sludge recirculation rate from $5.2 \mathrm{~L} / \mathrm{d}$ to $25 \mathrm{~L} / \mathrm{d}$. The stability of the digester sludge at recirculation rate 25 $\mathrm{L} / \mathrm{d}$ remains same to $5.2 \mathrm{~L} / \mathrm{d}$. It meant the digester was still stable even at a high sludge recirculation rate $25 \mathrm{~L} / \mathrm{d}$. The SMA of the UASB sludge at $15{ }^{\circ} \mathrm{C}$ became higher at an increasing sludge recirculation rate. This can be attributed to an improved conversion of sewage solids to $\mathrm{CH}_{4}$ and biomass, and an increased supply of methanogens to the UASB sludge.

Table 4. The SMA of UASB sludge at $15^{\circ} \mathrm{C}$, and the stability of UASB and digester sludge at $35^{\circ} \mathrm{C}$.

\begin{tabular}{|c|c|c|c|}
\hline \multirow{2}{*}{$\begin{array}{l}\text { Sludge } \\
\text { recirculation rate } \\
(\mathrm{L} / \mathrm{d})\end{array}$} & \multicolumn{2}{|c|}{$\begin{array}{c}\text { Stability } \\
\text { (g-COD/g-COD) }\end{array}$} & \multirow{2}{*}{ 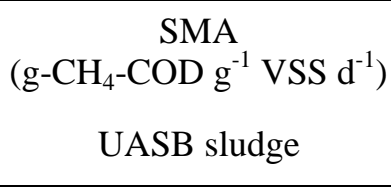 } \\
\hline & $\begin{array}{l}\text { UASB } \\
\text { sludge }\end{array}$ & $\begin{array}{l}\text { Digester } \\
\text { sludge }\end{array}$ & \\
\hline $1.8(0.9 \%)^{*}$ & 0.37 & - & 0.040 \\
\hline $5.2(2.6 \%)^{*}$ & 0.15 & 0.01 & $0.048(0.002)^{* *}$ \\
\hline $25(12.5 \%)^{*}$ & 0.10 & 0.01 & $0.067(0.003)^{* *}$ \\
\hline
\end{tabular}

* the sludge recirculation rate as percentage of the influent flow rate is given between brackets

** standard deviation; three samples were taken at the same time 


\section{Methane production}

The methane production as a fraction of total COD input and COD removed is shown in Table 5. It is clear that both $\mathrm{COD}_{\text {methane }} / \mathrm{COD}_{\text {in }}$ and $\mathrm{COD}_{\text {methane }} / \mathrm{COD}_{\text {removed }}$ were higher with an increasing sludge recirculation rate. The $\mathrm{COD}_{\text {methane }} / \mathrm{COD}_{\text {removed }}$ increased from 0.55 to 0.77 as sludge recirculation rate increased from $1.8 \mathrm{~L} / \mathrm{d}$ to $5.2 \mathrm{~L} / \mathrm{d}$. This confirmed that suspended COD accumulated (as discussed earlier) when operating at low circulation rate of $1.8 \mathrm{~L} / \mathrm{d}$, since suspended COD removal efficiencies were similar at these two sludge circulation rates (see Table 2). The $\mathrm{COD}_{\text {methane }} / \mathrm{COD}_{\text {removed }}$ reached 0.92 when the sludge recirculation rate increased to $25 \mathrm{~L} / \mathrm{d}$. It indicated a high anaerobic biodegradability of COD removed. Elmitwalli (2001) also reported that the anaerobic bio-degradability of suspended solids in domestic sewage was $78 \%$ at $30{ }^{\circ} \mathrm{C}$, however, without taking into consideration of dissolved methane. In this research, the $\mathrm{COD}_{\text {methane }}$ included two parts, which were the collected $\mathrm{CH}_{4}$ gas and the dissolved $\mathrm{CH}_{4}$ in the effluent of U-D system. Assuming that the dissolved $\mathrm{CH}_{4}$ was saturated in the effluent, it was calculated by Henry's law. However, the actual $\mathrm{COD}_{\text {methane }} / \mathrm{COD}_{\text {removed }}$ might be lower if $\mathrm{CH}_{4}$ was not saturated in the effluent.

Table 5 also shows the biogas production. A large part of the methane production $\left(5.86 \mathrm{~L}-\mathrm{CH}_{4} / \mathrm{d}\right.$ according to Henry's law) in the UASB was dissolved in the effluent and combined with a low dissolved COD removal efficiency, the amount of biogas collected in the UASB was very low. It was higher after sludge recirculation rate increased from $5.2 \mathrm{~L} / \mathrm{d}$ to $25 \mathrm{~L} / \mathrm{d}$. This confirmed that, the high dissolved COD removal (in Table 3) at sludge recirculation rate $25 \mathrm{~L} / \mathrm{d}$ was indeed partially due to a large amount of methanogens supplied from the digester to the UASB. It enhanced the conversion of dissolved COD to methane in the UASB. The bio-gas production in the digester significantly increased after the sludge recirculation rate had increased from $1.8 \mathrm{~L} / \mathrm{d}$ to $5.2 \mathrm{~L} / \mathrm{d}$. However, it did not rise any further at a sludge recirculation rate of $25 \mathrm{~L} / \mathrm{d}$. The reason might be that the bio-gas production of the digester is not only depended on the captured $\mathrm{COD}_{\text {suspended }}$ from the UASB sludge bed, but also its anaerobic degradability at $35^{\circ} \mathrm{C}$.

Assuming that the suspended COD could be efficiently converted to methane, the methane production in the digester could be calculated in the following formula (1):

$$
\mathrm{V}_{\mathrm{CH}_{4}=}=\mathrm{COD}_{\text {suspended }} \times \mathrm{Q}_{\text {influent }} \times \mathrm{D}_{\text {anaerobic bio-degradablity }} \times 0.35
$$

Where $\mathrm{V}_{\mathrm{CH}_{4}}$ is the methane production ( $\left.\mathrm{L} / \mathrm{d}\right)$; $\mathrm{COD}_{\text {suspended }}$ is the concentration of suspended COD in the influent $(\mathrm{mg} / \mathrm{L})$; $Q_{\text {influent }}$ is the influent flow rate of U-D (L/d); D is the anaerobic biodegradability of suspended solids, which was 0.78 in Elmitwalli's et al. (2001) research, but 0.5 was used in this work on the safe consideration. The methane production in theory should be about 10.5 $\mathrm{L} / \mathrm{d}$ in this research. Assuming a $40 \mathrm{~kJ} / 1 \mathrm{CH}_{4}$ methane heat combustion and an efficiency of $80 \%$, about $336 \mathrm{~kJ} / \mathrm{d}$ heat could be obtained. It is enough to warm up the transferred sludge from the UASB to the digester from $15^{\circ} \mathrm{C}$ to $35^{\circ} \mathrm{C}$, whose recirculation rate is equivalent with $2-2.5 \%$ of the influent flow rate $(200 \mathrm{~L} / \mathrm{d})$.

The sludge recirculation rates $1.8 \mathrm{~L} / \mathrm{d}, 5.2 \mathrm{~L} / \mathrm{d}$ and $25 \mathrm{~L} / \mathrm{d}$ applied in this research represent $0.9 \%$, $2.6 \%$ and $12.5 \%$ of influent flow rate respectively. Based on the biogas production, COD removal efficiency and the economy of sludge heating, a sludge circulation rate of $2.6 \%$ of the influent flow is recommended. 
Table 5. Methane production at different sludge recirculation rates (including gaseous and effluent saturated with dissolved methane).

\begin{tabular}{lccc}
\hline Sludge recirculation rate $(\mathrm{L} / \mathrm{d})$ & 1.8 & 5.2 & 25 \\
\hline $\mathrm{COD}_{\text {methane }} / \mathrm{COD}_{\text {in }}(\mathrm{g} / \mathrm{g})$ & 0.19 & 0.23 & 0.3 \\
$\mathrm{COD}_{\text {methane }} / \mathrm{COD}_{\text {removed }}(\mathrm{g} / \mathrm{g})$ & 0.55 & 0.77 & 0.92 \\
$\mathrm{Bio}-\mathrm{gas} *_{\text {digester }}(\mathrm{L} / \mathrm{d})$ & 2.9 & 7.4 & 7.5 \\
Bio-gas ** & 0.31 & 0.37 & 1.22 \\
\hline * the percentage of methane is $66 \%$ & & \\
$* *$ the percentage of methane is $78 \%$ & &
\end{tabular}

The COD concentrations of influent and effluent are shown in Fig.2 for the different sludge recirculation rates. The dissolved COD concentration contributed from $46 \%$ to $53 \%$ to total influent COD and this was similar for the suspended COD. The dissolved COD removal efficiency increased about $12 \%$ after sludge recirculation rate increased from $5.2 \mathrm{~L} / \mathrm{d}$ to $25 \mathrm{~L} / \mathrm{d}$. However, it only somewhat improved the total COD removal efficiency. Thus, both the $\mathrm{COD}_{\text {methane }} / \mathrm{COD}_{\text {in }}$ and total COD removal efficiency were low even with $25 \mathrm{~L} / \mathrm{d}$ sludge recirculation rate. The dissolved COD was difficult to remove at $15{ }^{\circ} \mathrm{C}$ in the U-D system and was the main part of the effluent (51$57 \%)$. A high contribution of dissolved COD (70\%) to total effluent COD was also reported by Álvarez et al. (2004), who also had a high fraction of dissolved COD in the influent (Figure 2). Mahmoud et al. (2004), however, had a low fraction of influent dissolved COD, which resulted in a high total COD removal efficiency. This shows that the influent dissolved to total COD ratio is a key factor in achieving high COD removal efficiency in a UASB-digester system. Elmitwalli et al. (2001) also showed that the maximum conversion of the dissolved COD in domestic sewage was only $62 \%$ even at $30{ }^{\circ} \mathrm{C}$, this further emphasizes that the removal of dissolved COD is the main challenge in low temperature anaerobic treatment. It highlights that the lack of methanogens leads to a poor dissolved COD removal efficiency. Thus, longer SRT (Gomec 2010, Speece 2008) and plenty of methanogens are required to enhance the removal efficiency of dissolved COD at low temperature.

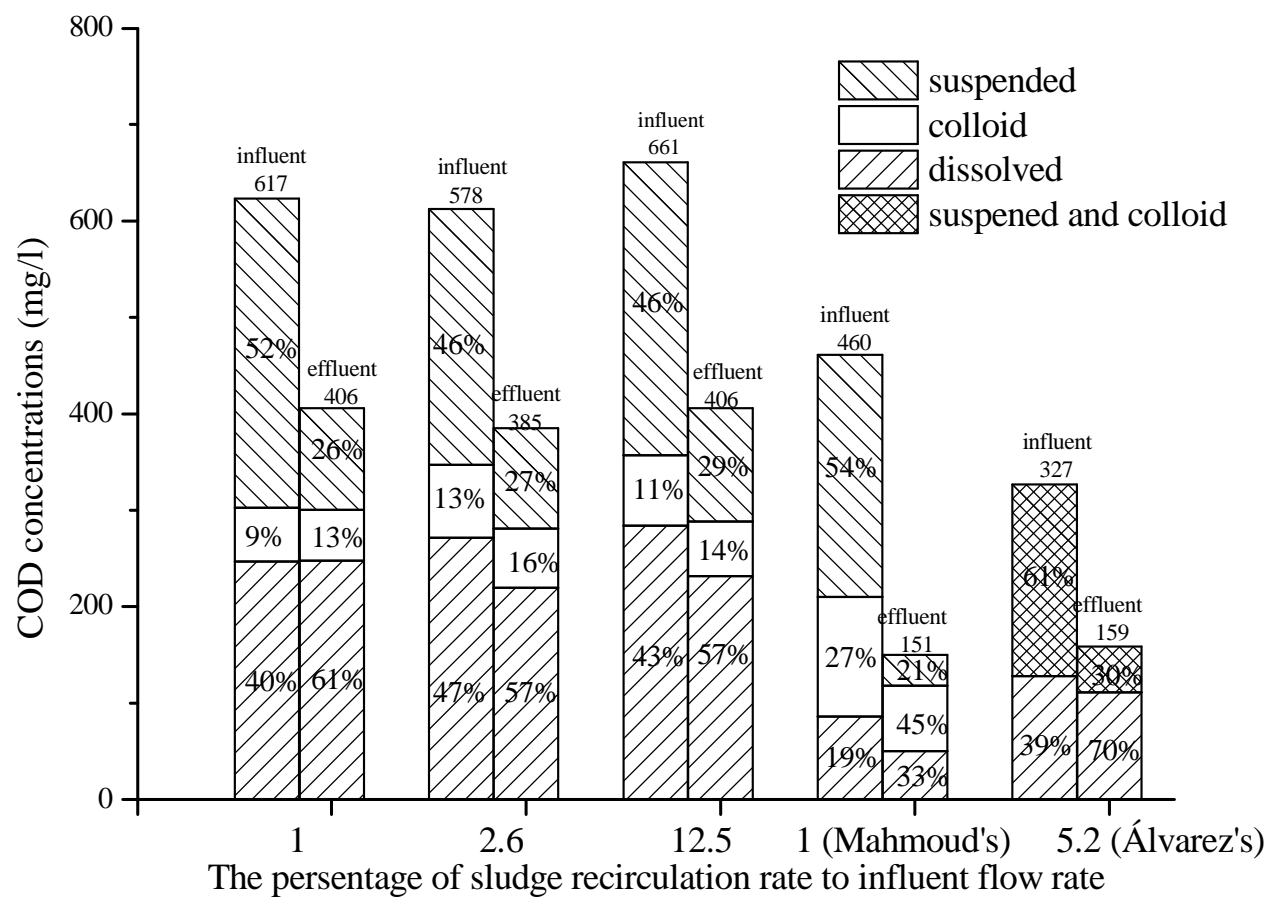

Figure 2. Comparison of COD characteristics in this research and other researchers' during different percentage of sludge recirculation rate to influent flow rate. 


\section{Conclusions}

Anaerobic treatment of domestic sewage at low temperature is feasible in a UASB-digester system. The removal of dissolved COD was limiting, especially at a high dissolved to total COD ratio in the influent.

Three sludge recirculation rates between UASB $\left(15^{\circ} \mathrm{C}\right)$ and digester $\left(35^{\circ} \mathrm{C}\right)$ were tested, a higher sludge recirculation rate resulted in:

- Increase in total COD removal efficiency, mainly caused by the transfer of dissolved COD to the digester

- Improved conversion of removed COD to methane

- Improved stability of the sludge in the UASB

Based on the potential energy available in the waste water, a sludge recirculation flow of $2-3 \%$ of the influent flow is recommended.

\section{Acknowledgements}

This study was financed by Technology Foundation STW, the Netherlands (project 07736). Zhang Lei received the financial support of The China Scholarship Council and the project 2009ZX07317008-01 (The common property key technology research and demonstration project of the wastewater pollution control and treatment in cold towns).

\section{References}

Álvarez, J. A., E. Armstrong, J. Presas, M. Gómez \& M. Soto (2004) Performance of a UASBdigester system treating domestic wastewater. Environ. Technol., 25(10), 1189-1199.

Elmitwalli, T. A., J. Soellner, A. De Keizer, H. Bruning, G. Zeeman \& G. Lettinga (2001) Biodegradability and change of physical characteristics of particles during anaerobic digestion of domestic sewage. Water Res., 35(5), 1311-1317.

Gomec, C. Y. (2010) High-rate anaerobic treatment of domestic wastewater at ambient operating temperatures: A review on benefits and drawbacks. Journal of Environmental Science and Health - Part A Toxic/Hazardous Substances and Environmental Engineering, 45(10), 1169-1184.

Langenhoff, A. A. M. \& D. C. Stuckey (2000) Treatment of dilute wastewater using an anaerobic baffled reactor: Effect of low temperature. Water Research, 34(15), 3867-3875.

Leitão, R. C., A. C. Van Haandel, G. Zeeman \& G. Lettinga (2006) The effects of operational and environmental variations on anaerobic wastewater treatment systems: A review. Bioresource Technology, 97(9), 1105-1118.

Lettinga, G., S. Rebac \& G. Zeeman (2001) Challenge of psychrophilic anaerobic wastewater treatment. Trends in Biotechnology, 19(9), 363-370.

Luostarinen, S., W. Sanders, K. Kujawa-Roeleveld \& G. Zeeman (2007) Effect of temperature on anaerobic treatment of black water in UASB-septic tank systems. Bioresource Technology, 98(5), 980-986.

Mahmoud, N., G. Zeeman, H. Gijzen \& G. Lettinga (2004) Anaerobic sewage treatment in a onestage UASB reactor and a combined UASB-Digester system. Water Res., 38(9), 2347-2357.

Mahmoud, N., G. Zeeman \& J. B. van Lier (2008) Adapting UASB technology for sewage treatment in Palestine and Jordan. Water Science and Technology.

McKeown, R. M., C. Scully, A. M. Enright, F. A. Chinalia, C. Lee, T. Mahony, G. Collins \& V. O'Flaherty (2009) Psychrophilic methanogenic community development during long-term cultivation of anaerobic granular biofilms. ISME Journal, 3(11), 1231-1242. 
Seghezzo, L., C. M. Cuevas, A. P. Trupiano, R. G. Guerra, S. M. González, G. Zeeman \& G. Lettinga (2006) Stability and activity of anaerobic sludge from UASB reactors treating sewage in subtropical regions. Water Science and Technology.

Speece, R. E. (2008) Anaerobic Biotechnology and Odor/Corrosion Control for Municipalities and Industries. Archae Press, Nashville. 